\title{
Svěřenský fond jako nástroj vhodný ke správě výživného určeného $k$ tvorbě úspor
}

\section{Trust Fund as an Instrument Suitable for Administration of the Child Maintenance Designed to Create Savings}

\author{
Martina Grochová*, Vlastimil Vitoul ${ }^{* *}$
}

\begin{abstract}
Abstrakt
Př̌spèvek pojednává o institutu výživného určenébo k tvorbě úspor, jebo smyslu a účelovém určení takto naspořných částek. Autorì se zamýsli nad úskalimi spojenými se soucasnou úpravou správy takto nasporených částech. Př̌spèvek predstavuje institut svěrenského fondu jakožto flexibilni nástroj vhodný pro efektivní správu majetku. Demonstruje jaké výhody by mobla prìnést mo:̌̃nost vyựití svěrenskébo fondu pro správu výżivnébo urč́nébo k tvorbè úspor.
\end{abstract}

\section{Klíčová slova}

Správa ciz̨ího majetku; svèrenský fond; plná správa ciz̨ího majetku; výživné; úspory; vyživovaci povinnost; správa jmèni dítète.

\section{Abstract}

This paper discusses the institute of the maintenance designed to create savings and the intended purpose of thus saved finances. The authors consider the pitfalls of the current legal regulation of the administration of thus saved finances. The paper presents the trust fund as a flexible tool suitable for an effective administration of the property. It demonstrates the advantages of the possibility of the use of the trust fund for the administration of the maintenance designed to create savings.

\section{Keywords}

Fiduciary; Czech Trust Fund; Full Fiduciary; Maintenance; Savings; Maintenance Obligation; Administration of the Child's Wealth.

\section{1 Úvod}

Tento prríspěvek propojuje dva na první pohled nesouvisející instituty soukromého práva, a to výživné pro nezletilé dítě určené k tvorbě úspor a svěřenský fond. Cílem autorů je kritickým zpo̊sobem přiblížit opomíjenou možnost stanovit výživné určené k tvorbě úspor pro nezletilé dítě, poukázat na úskalí současné právní úpravy a navrhnout konstruktivní řešení vybrané problematické situace objevující se při správě a nakládání s takto naspo-

\footnotetext{
* Mgr. Martina Grochová, doktorandka, Katedra ústavního práva a politologie, Právnická fakulta Masarykovy univerzity, Brno / Ph.D. student, Department of Constitutional Law and Political Science, Faculty of Law, Masaryk University, Brno, Czech Republic / E-mail: mgrochova@mail.muni.cz

** Mgr. Vlastimil Vitoul, doktorand, Katedra občanského práva, Právnická fakulta Masarykovy univerzity, Brno / Ph.D. student, Department of Civil Law, Faculty of Law, Masaryk University, Brno, Czech Republic / E-mail: vitoul.vlastimil@gmail.com
} 
řenými prostředky. Jako vhodné řešení se autoři rozhodli navrhnout využití svěřenského fondu, který do českého právního řádu přinesla rekodifikace soukromého práva.

Jednou z nosných idejí rekodifikace soukromého práva bylo jeho funkční určení jako nástroje sloužícího člověku k prosazování jeho svobody. Účelem zákona č. 89/2012 Sb., občanský zákoník (dále jen „občanský zákoník“), pak je mj. umožnit i garantovat svobodné utváření soukromého života a ponechat tedy co nejširší prostor svobodné iniciativě jednotlivce. ${ }^{1} \mathrm{~V}$ oblasti správy majetku se výše uvedená idea promítla nabídkou širokého spektra právních nástrojů sloužících ke správě majetku, jež se vzájemně překrývajî či doplňují. Zákonodárce tímto dal velkou volnost při výběru vhodného právního nástroje vyhovujícího zájmům a představám adresátů práva pro konkrétní životní situace.

Mediálně nejvýraznějším prostředkem správy majetku je bezesporu svěřenský fond, jenž bývá prezentován ve velmi negativních konotacích. Mnohdy nedůvodná kritika vede k minimálnímu užívání svěřenských fondů a nutí ty, jež mají o jeho využití zájem, aby užívali spíše institutů zahraničních právních řádů, které slibují větší právní jistotu - zároveň jsou však v otázkách vytýkaných svěřenským fondům mnohem rizikovější a jsou s nimi spojeny i výrazně větší zřizovací a provozní náklady. Důvodem k užití zahraničních nástrojů svěřenským fondům funkčně obdobným je zejména výše uváděný negativní mediální obraz svěřenských fondư ${ }^{2}$ jemuž však chybí věcná opora, nebot' problematické otázky týkající se svěřenských fondů byly na odborné úrovni ve značné míře objasněny ${ }^{3}$. Dalším z důvodů jejich nízkého využití je určitá míra neochoty aplikační praxe učit se novým věcem a užívat je pro řešení životních situací, kde je možné dosáhnout výsledku za užití osvědčených, byt' méně vhodných, nástrojů.

Autoři se $\mathrm{v}$ př́spěvku pokusí přiblížit svěrenský fond jako flexibilní nástroj vhodný pro efektivní správu majetku a nastíní jeho možné využití pro oblast správy výživného určeného k tvorbě úspor. Právo dítěte na výživné, respektive povinnost rodiče výživné dítěti poskytovat je upravena v novém občanském zákoníku, ${ }^{4}$ jeho základ však lze hledat v ústavním pořádku jakožto součást práva na rodičovskou výchovu a péči, která je garantována Listinou základních práv a svobod. ${ }^{6}$ Úprava obsažená v novém občanském zákoníku byla ze značné části převzata ze zákona č. 94/1963 Sb., o rodině (dále jen „zá-

1 Důvodová zpráva k občanskému zákoníku, s. 20.

2 K otázkám negativního mediálního obrazu svěřenských fondů blíže viz VITOUL, Vlastimil, PONDIKASOVÁ, Tereza. Svěřenský fond jako efektivní nástroj správy cizího majetku? In: HURDÍK, J., LAVICKÝ, P., VALDHANS, J. Dny práva 2014 - DAYS OF LAW 2014. Brno: Masarykova univerzita, 2015, s. 475-482, 8 s. ISBN 978-80-210-7897-0.

3 K problematickým otázkám svěřenských fondů a adaptabilite svěřenských fondů v českém právním řádu viz TICHÝ, Luboš, RONOVSKÁ, Kateřina, KOCÍ, Miloš. Trust a srovnatelné instituty v Evropě. 1. vyd., Praha: Nakladateství Eva Rozkotová (Centrum právní komparatistiky PrF UK), 2014.

4 Pojem nový občanský zákoník v tomto článku odkazuje na zákon č. 89/2012 Sb., občanský zákoník.

5 FRANCOVÁ, Marie, DVOŘÁKOVÁ ZÁVODSKÁ, Jana. Rozvody, rozchody a zánik partnerství. Praha: ASPI, Wolters Kluwer, 2008, s. 21.

6 Článek 32 odst. 4 Listiny základních práv a svobod. 
kon o rodině‘‘), který byl občanským zákoníkem zrušen. Oblast vyživovací povinnosti rodiče $\mathrm{k}$ dítěti patří $\mathrm{k}$ těm, které vlivem rekodifikace doznaly pouze drobnějších změn. Zásadnější změny se odehrály spíše ve vztahu k systematickému zařazení této úpravy, než ve vztahu k jejímu obsahu.

Tento institut, jenž má svůj původ již v římském právu ${ }^{8}$ a jehož smysl a účel se může zdát na první pohled zřejmý, zůstává palčivým tématem oblasti rodinného práva. Přestože soudy rozhodují ročně konstantně kolem 100000 případů stanovení, zrušení, zvýšení či snížení vyživovací povinnosti rodičů k dětem, ${ }^{9}$ tato oblast práva je stále poněkud obskurní a zůstává mimo zájem odborné veřejnosti, což se negativně podepisuje jednotnosti a předvídatelnosti soudního rozhodování v této oblasti.

Ve vztahu k problematice určování formy a výše výživného pro děti vyvstává celá řada otázek. Jednou z nich je otázka spotřebního charakteru výživného a možnosti tvorby úspor ze soudem stanovených dávek výživného. Autoři se v př́spěvku rozhodli demonstrovat možnost využití svěřenského fondu jako řešení současné neefektivní a problematické právní úpravy správy výživného určeného k tvorbě úspor. Představují svěřenský fond jako vhodnou alternativu pro správu takto naspořených prostředků ve prospěch dítěte, která vylučuje zneužití výživného nespotřebního charakteru pro účely rodiče povinného (v př́padě, že jsou finance uloženy na účtu, k němuž mají dispoziční právo oba rodiče) nebo rodiče, jemuž bylo dítě svěřeno do výchovy (v případě, že je výživné určené k tvorbě úspor hrazeno k jeho rukám).

Př́spěvek nejprve stručně pojednává o charakteru výživného, tak jak je v současné chvíli upraveno v občanském zákoníku. Nastiňuje účel a smysl výživného určeného k tvorbě úspor a dále poukazuje na problematickou úpravu správy výživného určeného $\mathrm{k}$ tvorbě úspor pro nezletilé dítě. Zamýšlí se nad možnými modely správy takto naspořených finančních prostředků, které připouští současná právní úprava. Ve své druhé části pak nabízí alternativní řešení správy těchto prostředků, a to za využití svěřenského fondu. Př́íspěvek svěřenský fond nejprve stručně představuje a následně představuje výhody, které by možnost jeho využití v této oblasti mohla prrinést", a navrhuje taktéž v hrubých rysech možnou právní úpravu, která by zrřizení svěřenského fondu pro účely správy výživného umožnila.

$7 \mathrm{~K}$ nové úpravě výživného v novém občanského zákoníku více viz KRÁLÍČKOVA, Zdeňka, TELEC, Ivo. Výživné v novém občanském zákoníku. Bulletin advokacie. 2014, č. 3, s. 23-45.

8 SCHWENZER, Ingebor, DIMSEY, Mariel. Model Family Code from a Global Perspective. Antverpy - Oxford: Intersentia, 2006, s. 166.

9 Př́slušné statistiky jsou dostupné prostřednictvím webových stránek Českého statistického úřadu. V roce 2013 bylo rozhodnuto napríklad rozhodnuto 96137 prrípadů týkajících se vyživovací povinnosti $\mathrm{k}$ nezletilým dětem a dalších 4897 př́padů týkajících se vyživovací povinnosti $\mathrm{k}$ dětem zletilým. Srov. Soudnictví a kriminalita. Rožbodnutí soudů v ř̌zeni o nezletilých [online]. Český statistický úrad, 2014 [cit. 3. 3. 2016]. Dostupné z: https://www.czso.cz/documents/10180/25707202/3000026615.pdf/ed09f4cc-0984-4c3f-83 cd-8feaadd9521c?version=1.1 a Soudnictví a kriminalita. Rozbodnutí soudi v občanskoprámnich vě́ech [online]. Český statistický úřad, 2014 [cit. 3. 3. 2016]. Dostupné z: https://www.czso.cz/ documents/10180/25707202/3000026614.pdf/a6e79233-9c13-4d8c-b91b-382694bea4ae?version=1.1 


\section{Spotřební charakter výživného?}

Pojem výživné je sám o sobě z hlediska jazykového poněkud zavádějící. Vyvolává totiž mylný dojem, že výživné je určeno právě pouze k výživě oprávněné osoby. Ve skutečnosti je však výživné třeba chápat podstatně šiřeji než pouze jako dávku sloužící k zajištění výživy. Jeho účelem je zabezpečení odůvodněných potřeb oprávněného, jde tak o jeho celkové zaopatření, uspokojování nejen výživy v užším smyslu, ale taktéž uspokojování další potřeb. ${ }^{10}$ Výživou dítěte je míněno zajištění všech životních potřeb nezbytných pro jeho všestranný rozvoj, a to po stránce fyzické i duševní. ${ }^{11}$ Jde tedy vedle samotné výživy o zajišt'ování potřeb hmotných, jakými jsou ošacení či hračky, ale také nehmotných, zejména vzdělání dítěte. ${ }^{12}$ Přestože tedy pojem výživného odkazuje zejména na jeho funkci zajištění výživy oprávněného, je třeba mít na paměti, že jeho účel je podstatně širší. Svým účelem spadá výživné do soukromoprávního institutu zaopatření a patří mezi zaopatřovací závazky vznikající ze zákona. ${ }^{13}$

S tím taktéž úzce souvisí ustanovení \ 915 občanského zákoníků, které stanoví zásadu shodné životní úrovně dítěte a jeho rodičů. Výslovně je přitom stanoveno, že toto hledisko předchází hledisku odůvodněných potřeb. To znamená, že je-li úroveň rodiče velmi nízká, výživné nemusí dosahovat ani takové výše, která by pokryla odůvodněné potřeby dítěte. Zároveň však, což je zvlášt' dưležité právě pro otázku stanovení výživného určeného k tvorbě úspor, může být výživné stanoveno v takové výši, která bude rozsah odůvodněných potřeb dítěte přesahovat. ${ }^{14}$

Pojem shodná životní úroveň byl do české právní úpravy výživného zaveden novelou zákona o rodině z roku 1998, ${ }^{15}$ která taktéž poprvé výslovně zakotvila možnost stanovení výživného určeného $\mathrm{k}$ tvorbě úspor pro děti. Teorie rodinného práva i rozhodovací praxe vycházela do té doby z pravidla, že výživné pro dítě má zásadně spotřební charakter. ${ }^{16}$ Bylo judikováno, že výživné má sloužit svému spotřebnímu určení a nemá vést k postup-

10 KRÁLÍČKOVA, Zdeňka, TELEC, Ivo. Výživné v novém občanském zákoníku. Bulletin advokacie. 2014, Č. 3, s. 24.

11 HOLUB, Milan, NOVÁ, Hana, PTÁČEK, Lubomír, SLADKÁ HYKLOVÁ, Jana. Zákon o rodiněs komentárem, judikaturou a prédpisy souvisicimi. 9. vyd., Praha: Leges, 2011, s. 315.

12 ŠÍNOVÁ, Renata a kol. Řizeni ve vècech rodinněprávnich v České republice, Slovenské republice a Nèmecku. Praha: Leges, 2010, s. 174.

13 KRÁLÍČKOVA, Zdeňka, TELEC, Ivo. Výživné v novém občanském zákoníku. Bulletin advokacie. 2014, Č. 3, s. 24.

14 HOLUB, Milan, NOVÁ, Hana, PTÁČEK, Lubomír, SLADKÁ HYKLOVÁ, Jana. Zákon o rodiněs komentárem, judikaturou a prédpisy souvisicími. 9. vyd., Praha: Leges, 2011, s. 321.

15 Zákon č. 91/1998 Sb., kterým se mění a doplňuje zákon č. 94/1963 Sb., o rodině, ve znění pozdějších předpisů, a o změně a doplnění dalších zákonů.

16 ŠVESTKA, Jiří, DVOŘÁK, Jan, FIALA, Josef, ZUKLÍNOVÁ, Michaela a kol. Občanský quakoník. Komen-

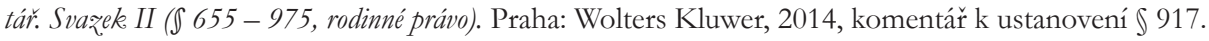


né tvorbě dlouhodobých úspor. ${ }^{17}$ Spotřební charakter byl výslovně stanoven zákonem do roku 1989, tendence takto pojímat výživné však nevymizela ani poté, a to až do chvíle, kdy výše citovaná novela výslovně zavedla zásadu shodné životní úrovně. ${ }^{18}$ Od této chvíle již není pochyb, že bylo upuštěno od modelu spotřebního charakteru výživného. Účelem výživného tak od provedené novely není jen čistá spotřeba, ale především zajištění shodné životní úrovně oprávněného dítěte a povinného rodiče, a to včetně tvorby úspor. ${ }^{19}$

\section{Výživné určené $\mathrm{k}$ tvorbě úspor}

Právě nový pohled na výživné jako plnění, které nemá nezbytně pouze spotřební charakter, umožnil také začlenění ustanovení, které dává možnost soudu uložit povinnost k tvorbě úspor pro dítě. Tuto povinnost vložil zákonodárce do ustanovení \917 nového občanského zákoníku, který stanoví, že:

„Rozhoduje-li soud o vyživovaci povinnosti rodiče $k$ ditèti nebo o vyživovaci povinnosti predka k nezletilému ditèti, keteré nenabylo plné svéprávnosti, a majetkové pomèry osoby výživou povinné to prïpouštèji, lie za odivvodnèné potreby dítěte považovat i tvorbu úspor, nevylučuji-li to okolnosti zulástního prípadu; poskytnuté výživné prècházi do vlastnictvi ditète. O správè takto poskytnutých ćástek platí obecná pravidla o jmèni ditète. "

Toto ustanovení je částečně pozměněným a formulačně upraveným přepisem dosavadní právní úpravy. ${ }^{20}$ Oproti úpravě obsažené v ustanovení \85a zákona o rodině je vyjádření poněkud podrobnější. Vypuštěna je ta část ustanovení, která prŕíkladmo uváděla účel tvorby úspor, kterým podle zákona o rodině mohlo být zabezpečení prostředků na př́ipravu na budoucí povolání. Tento účel byl akcentován zákonem zejména proto, že právě na možnosti zajištění vzdělání dětí je největší společenský zájem, uveden byl však pouze demonstrativně. ${ }^{21}$ Vypuštění této části ustanovení proto není třeba přikládat žádný zásadní význam. Na rozdíl od Svobody ${ }^{22}$ se tak nedomníváme, že by původní znění v tomto směru poskytovalo lepší oporu pro posouzení, kdy je tvorba úspor namístě, nebot' původní znění prríkladmo uvádělo pouze jediný možný účel, představitelná je přitom celá škála využití takto vytvořených úspor. Významnou změnou je naopak věta druhá ustanovení \ 917 občanského zákoníku, která výslovně stanovila způsob správy takto poskytnutých částek. O správě výživného určeného k tvorbě úspor bude pojednáno níže.

17 Srov. např. usnesení pléna Nejvyššího soudu ze dne 23. 6. 1967, sp. zn. Pls 4/1967.

18 ŠVESTKA, Jiří, DVOŘÁK, Jan, FIALA, Josef, ZUKLÍNOVÁ, Michaela a kol. Občanský zákoník. Komentár. Svazek II (』 655 - 975, rodinné právo). Praha: Wolters Kluwer, 2014, komentár k ustanovení $\int 917$.

19 HRUŠÁKOVÁ, Milana, KRÁLÍČKOVÁ, Zdeňka, WESTPHALOVÁ, Lenka a kol. Občanský zákoník II. Rodinné právo (』 655 - 975). Praha: C. H. Beck, 2014, s. 1066.

20 Důvodová zpráva k zákonu č. 89/2012, občanskému zákoníku, k \915 až 918.

21 HOLUB, Milan, NOVÁ, Hana, PTÁČEK, Lubomír, SLADKÁ HYKLOVÁ, Jana. Zákon o rodině s komentárem, judikaturou a prèdpisy souvisicimi. 9. vyd., Praha: Leges, 2011, s. 331.

22 SVOBODA, Karel. K tvorbě úspor ve prospěch dítěte. Právní roz̧bledy, 2014, č. 12, s. 437. 
Na výživné určené k tvorbě úspor je mnohdy pohlíženo jako na určitý luxus, na který dosáhnou pouze děti rodičů s nadprůměrnými př́jmy. ${ }^{23}$ Domníváme se, že takový pohled je třeba jako mylný odmítnout. Je třeba považovat za přirozený postup, kdy člověk průběžně ve svém životě zachází se získanými financemi takový způsobem, aby byl schopen uspokojit nejen své aktuální potřeby, ale také svoje potřeby budoucí. V době kdy tedy dosahuje př́ijmů, které nespotřebuje na krytí svých aktuálních potřeb a udržení dosažené životní úrovně, lze rozumně očekávat, že si část svých zisků šetří pro očekávané či neočekávané budoucí zvýšené výdaje. To přitom platí nejen u osob s extrémně vysokými př́jmy. Má-li se tedy dítě podílet na životní úrovni svých rodičů, má mít možnost tvorby finanční rezervy pro případ budoucích zvýšených výdajů, má-li takovou možnost také jeho rodič. Proto je také výše citované ustanovení formulováno tak, že tvorbu úspor lze za odůvodněnou potřebu považovat zásadně vždy, připouštějí-li to majetkové poměry osoby výživou povinné. ${ }^{24}$

Současná právní úprava tedy počítá s tím, že dítě má právo na tvorbu úspor, pokud to poměry povinného rodiče umožňují. Jako poněkud nesnadnější se však jeví otázka, k čemu mají být tyto úspory určeny, co z nich lze hradit, za jakým účelem mají být vytvářeny. Neexistuje ani jednotný náhled na to, zda má být účel takto vytvořených úspor předem určen a zda takové určení zavazuje do budoucna rodiče i samotné dítě k využití prostředků právě k tomuto účelu.

Pokud jde o to, pro jakou dobu jsou takto naspořené finance určeny, existují dva možné výklady. Bud’to lze dospět k závěru, že jsou úspory tvořeny za účelem krytí potřeb dítěte do doby, než je schopno se samo živit, nebo že jsou tyto úspory určeny taktéž pro období, kdy již je dítě schopno se samo živit jako jakýsi vstupní kapitál. ${ }^{25} \mathrm{O}$ tom, že tyto prostředky mohou být využity pro krytí potřeb po dobu, než je dítě schopno se samo živit, není v zásadě sporu. Panuje ovšem neshoda na tom, k čemu mohou být tyto úspory využity a zda je vhodné tento účel předem definovat.

V odborné literatuře se setkáme s celou škálou př́kladmo uvedených potřeb, které mohou být z takto vytvořených úspor kryty, at’ už jde o prrípravu na budoucí povolání, založení vlastní domácnosti a rodiny, budoucí přilepšení invalidnímu dítěti, získání budoucího bydlení, realizování finančně náročných zálib, ${ }^{26}$ vzdělání v zahraničí, finančně náročná léčba, ${ }^{27}$ zvýšené, avšak zpravidla běžné výdaje, ${ }^{28}$ zakoupení drahého vybavení pro sportovní či umělecké uplatnění, uzavření výhodného pojištění či zajištění výživy

23 Srov. např. VLK, Václav. Extrémní př́ijmy a tvorba úspor. Rodinné listy, 2015, č. 11, s. 7.

24 HRUŠÁKOVÁ, Milana, KRÁLÍČKOVÁ, Zdeňka, WESTPHALOVÁ, Lenka a kol. Občanský żákoník II. Rodinné právo (』 655 - 975). Praha: C. H. Beck, 2014, s. 1111.

25 Srov. např. SVOBODA, Karel. K tvorbě úspor ve prospěch dítěte. Právní roz̧bledy, 2014, č. 12, s. 437.

26 ŠVESTKA, Jiří, DVOŘÁK, Jan, FIALA, Josef, ZUKLÍNOVÁ, Michaela a kol. Občanský zákoník. Komen-

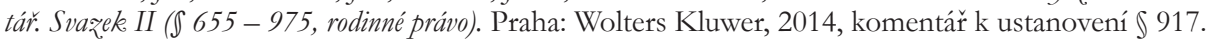

27 HRUŠÁKOVÁ, Milana, KRÁLÍČKOVÁ, Zdeňka, WESTPHALOVÁ, Lenka a kol. Občanský zákoník II. Rodinné právo (』 655 - 975). Praha: C. H. Beck, 2014, s. 1112.

28 SVOBODA, Karel. K tvorbě úspor ve prospěch dítěte. Právní roz̧hledy, 2014, č. 12, s. 437. 
dítěte do budoucna tam, kde není jistota, že povinný rodič bude schopen plnit vyživovací povinnost v odpovídající výši po celou dobu trvání vyživovací povinnosti. ${ }^{29} \mathrm{Je}$ tedy žrejmé, že zatímco někteří se domnívají, že výživné má být určeno výhradně k zabezpečení obvyklých zvýšených potřeb dítěte po dobu, kdy není schopno se samo živit, ${ }^{30}$ jiní počítají taktéž s možností využití úspor i pro start do samostatného života dítěte. ${ }^{31}$

Neztotožňujeme se s názorem, ${ }^{32}$ že takto naspořené prostředky nelze využít pro období, kdy je dítě již schopno se samo živit. V první radě se nedomníváme, že by takové využití právní úprava znemožňovala. Účel tvorby úspor prostřednictvím výživného není v zákoně nikterak vymezen. Domníváme se, že i možnost mít určitý vstupní kapitál pro samostatný život lze podřadit pod možnost sdílet shodnou životní úroveň rodičů, která (jak bylo výše vysvětleno) zahrnuje taktéž možnost mít úspory, umožňují-li to poměry povinného. Nadto není zřejmé, jakým způsobem by dle zastánců opačného názoru mělo být naloženo s již tímto zpưsobem vytvořenými úsporami, které v době, kdy dítě nebylo schopno se samo živit, nebyly spotřebovány.

Smysl a účel výživného určeného k tvorbě úspor tedy vnímáme spíše tak, jak jsou vnímány úspory v obecné rovině, tedy ke krytí potřeb v bezprostřední i vzdálené budoucnosti, a to ke krytí potřeb jasně předem definovaných i neočekávaných a nepředvídaných. Domníváme se proto, že úspory vytvořené v souladu s ustanovením \917 občanského zákoníku je možné využít pro krytí celé škály výše nastíněných potřeb dítěte, které mohou nastat jak v období, kdy není samo schopno se živit, tak i na počátku jeho samostatného života. Neztotožňujeme se tedy s názorem, ${ }^{33}$ že tvorba úspor by měla být nařízena pouze tehdy, pokud je zřejmé, že těchto úspor bude v budoucnu třeba ke krytí konkrétních dosud neexistujících výloh dítěte.

\section{Správa výživného určeného $\mathrm{k}$ tvorbě úspor}

At' už je však tvorba úspor nařízena za jakýmkoliv účelem, vyvstává otázka správy takto naspořených prostředků. Jak bylo uvedeno výše, oproti dosavadní úpravě v zákoně o rodině nový občanský zákoník tuto otázku výslovně upravuje, když v ustanovení \917 stanoví, že „poskytnuté výżivné prechází do vlastnictvi dítéte. O správè takto poskytnutých částek platí obecná pravidla o jmèni dítéte. "Dosavadní úprava neposkytovala žádnou oporu pro řešení otázky, kam mají být částky určené k tvorbě úspor pro dítě zasílány ani kdo a jakým způsobem je oprávněn s nimi nakládat. Dovozovalo se proto, že i tyto částky mají být, stejně

29 HOLUB, Milan, NOVÁ, Hana, PTÁČEK, Lubomír, SLADKÁ HYKLOVÁ, Jana. Zákon o rodině s komentárem, judikaturou a prédpisy souvisícimi. 9. vyd., Praha: Leges, 2011, s. 331.

30 SVOBODA, Karel. K tvorbě úspor ve prospěch dítěte. Právni roz̧bledy, 2014, č. 12, s. 437.

31 ŠVESTKA, Jiří, DVOŘÁK, Jan, FIALA, Josef, ZUKLÍNOVÁ, Michaela a kol. Občanský zákoník. Komen-

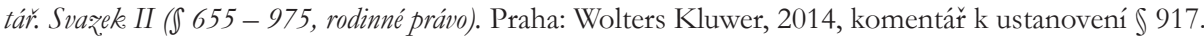

32 SVOBODA, Karel. K tvorbě úspor ve prospěch dítěte. Právni roẓhledy, 2014, č. 12, s. 437.

33 Tamtéž. 
jako běžné výživné, zasílány na účet rodiče (či instituce), který má dítě v péči, př́ipadně že je taktéž možné částky určené k tvorbě úspor ukládat na účet založený soudem nebo založený rodiči a soudem vinkulovaný. Negativně bylo pohlíženo na možnost, že by peníze byly ukládány na účet, s nímž by mohli disponovat oba rodiče. Ani takový názor však nebyl bezvýhradně přjímán. ${ }^{34}$

Nová právní úprava tyto nejasnosti zdánlivě odstranila. Jak se však ukazuje, ani v současnosti nepanuje shoda na tom, jak mají být úhrady výživného určeného k tvorbě úspor spravovány. $\mathrm{V}$ obecné rovině je správa jmění dítěte upravena v novém občanském zákoníku. ${ }^{35}$ Platí přitom, že oproti dřívější úpravě je ke správě jmění dítěte zásadně nezbytný souhlas soudu, nejedná-li se o běžné záležitosti nebo o záležitosti sice výjimečné, ale týkající se zanedbatelné majetkové hodnoty. Jednání bez souhlasu soudu je přitom považováno za jednání zdánlivé. ${ }^{36}$

Důvodová zpráva k tomu problému poskytuje jen stručné stanovisko. Uvádí se zde, že rodiče se musí dohodnout o zř́zení účtu, na který budou peníze ukládány a neučiní-li tak, mohou navrhnout, aby rozhodl soud. Pokud neučiní ani návrh k soudu, bude výživné včetně úspor plněno k rukám toho, komu bylo dítě svěřeno do péče. ${ }^{37} \mathrm{Z}$ toho je tedy zřejmé, že i přes zdánlivé zpřesnění právní úpravy přetrvává situace, kdy přicházî do úvahy uložení peněz jak na účtu, se kterým budou disponovat oba rodiče, tak na účtu zř́zeném soudem, tak i na účtu rodiče, který má dítě v péči.

I přes nově začleněné ustanovení se někteří domnívají, že je mylný názor, že úspory mají být ukládány na nově založený účet, $\mathrm{k}$ němuž mají dispoziční právo oba rodiče. Povinný rodič totiž nemá mít oprávnění s těmito prostředky disponovat. Peníze mají být ukládány na účet pečujícího rodiče, který je použije k pokrytí zvýšených avšak zpravidla běžných výdajů dítěte. Pouze v př́padě rizika zneužití prostředků pečujícím rodičem by měl soud ustanovit opatrovníka pro správu této části jmění dítěte ${ }^{38}$. Setkáme se však i se zcela protichůdným názorem, že takovýto postup je v souladu se současnou právní úpravou vyloučen. Úspory mají být uloženy na účtu na jméno dítěte a mají být spravovány oběma rodiči. Volba vhodného peněžního ústavu je v rukou rodičů, pokud se však nedohodnou, rozhodne soud. Soud by prritom zásadně neměl přijímat žádná omezující opatření. ${ }^{39}$ Je tak zřejmé, že zařazení věty druhé ustanovení \ 917 nového občanského zákoníku, je pouze zdánlivým řešením otázek správy výživného určeného k tvorbě úspor.

34 HOLUB, Milan, NOVÁ, Hana, PTÁČEK, Lubomír, SLADKÁ HYKLOVÁ, Jana. Zákon o rodiněs komentárem, judikaturou a predpisy souvisicimi. 9. vyd., Praha: Leges, 2011, s. 331-332.

35 Jmění dítěte může být spravováno bud' jeho rodiči (ustanovení \896-905 občanského zákoníku), poručníkem (ustanovení \ 934, 938, 941, 942 OZ) nebo opatrovníkem (ustanovení \948-952 OZ).

36 RADVANOVÁ, Senta a kol. Rodina a díté v novém občanském zákoníku. Praha: C. H. Beck, 2015, s. 92.

37 Důvodová zpráva k občanskému zákoníku, k J 915 až 918.

38 SVOBODA, Karel. K tvorbě úspor ve prospěch dítěte. Právní roz̧hledy, 2014, č. 12, s. 437.

39 HRUŠÁKOVÁ, Milana, KRÁLÍČKOVÁ, Zdeňka, WESTPHALOVÁ, Lenka a kol. Občanský zákoník II. Rodinné právo (J 655 - 975). Praha: C. H. Beck, 2014, s. 1112. 
Přestože tedy obecně lze považovat úpravu možnosti uložit povinnému rodiči taktéž tvorbu úspor jako chvályhodnou a prospěšnou, souhlasíme s názorem, ${ }^{40}$ že současná úprava správy takto vytvořených úspor není nejšt'astnější a domníváme se, že by měla být předmětem novelizace, a to jednak proto, že je nejasná a jednak proto, že se nejeví jako zcela vhodná a efektivní. Pokud bychom přistoupili na výklad, že mají být naspořené prostředky uloženy na účtu, s nímž mohou disponovat oba rodiče, jakékoliv nakládání s těmito financemi bude muset být schváleno soudem, nebot' potřeby, které budou hrazeny z úspor, budou ze své podstaty neběžného charakteru a majetkově významné hodnoty. Jakékoliv využití úspor pro dítě tak bude ztěžováno (a mnohdy i blokováno) časově i administrativně náročným procesem. Pokud naopak přistoupíme na výklad, že prostředky mají být uloženy na účtu rodiče, který má dítě ve výchově, znemožníme rodiči, který úspory pro dítě vytváří, aby se podílel na rozhodování o využití těchto financí či aby měl možnost jejich využití kontrolovat. Nadto je stále menší procento dětí svěřováno do výlučné výchovy jednoho rodiče, není tedy zřejmé, jak postupovat v takovém př́ípadě. Ani jedna z možností se tak nejeví jako zcela vhodná.

V následujícím textu představíme svěřenský fond a jeho možné využití pro správu výživného k tvorbě úspor. Přinášíme zejména úvahy nad tím, proč považujeme využití tohoto institutu za vhodné řešení shora nastíněných problematických aspektů správy úspor dítěte, a nastíníme v hrubých rysech i konkrétní možnou úpravu, která by umožnila zř́zení svěřenského fondu ke správě výživného určeného k tvorbě úspor.

\section{Svěřenský fond - efektivní nástroj správy majetku}

Svěřenský fond ${ }^{41}$ je právním transplantátem trustu, jenž se do českého právního řádu dostal při rekodifikaci soukromého práva završené v roce 2012. ${ }^{42}$ Trust jako právní nástroj pro správu cizího majetku je s oblibou užívaný po staletí zejména v zemích s angloamerickým právním systémem. Bývá nejčastěji definován jako právní vztah, kdy je majetek svěřen jiné osobě (správci), který je tento majetek povinen spravovat pro druhé. ${ }^{43}$ Svěřenský fond sice výše uvedenou definici trustu formálně naplňuje, avšak bez širších souvislostí plynoucích ze specifik angloamerického právního systému (zejména pak dvoukolejnost common law a equity) není možné svěřenský fond považovat za trust v pravém slova smyslu ${ }^{44}$, ale je na něj nutné nahlížet jako na svébytný institut, u nějž je patrná inspirace

40 Srov. např. SVOBODA, Karel. K tvorbě úspor ve prospěch dítěte. Právní roz̧bledy, 2014, č. 12, s. 437.

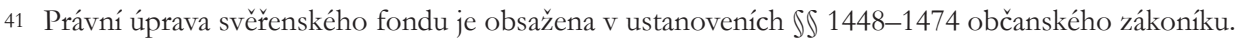

42 Česká republika se tak stala druhou evropskou zemí s kontinentálním systémem práva, která do svého právního řádu provedla právní transplantaci tohoto poněkud cizorodého prvku; první bylo v roce 1926 Lichtenštejnsko, a to z důvodu zatraktivnění země pro investory z oblasti zemí s anglo-americkou právní tradicí.

43 DUDDINGTON, John. Equity and trusts. 3rd ed.UK: Pearson Education Limited, 2011, s. 8.

$44 \mathrm{~K}$ hlubší analýze trustů viz např. LUPOI, Maurizio. Trusts: A Comaprative Study. Cambridge Studies in International and Comparative Law, 2001. 
v trustech. Česká právní úprava svěřenského fondu vychází zejména z quebecké právní úpravy trustů, která byla je hlavním inspiračním zdrojem pro český občanský zákoník. ${ }^{45}$ Civil Code of Québec byl v průběhu devatenáctého století silně ovlivněn francouzským právem, tedy právem kontinentálním.

Svěřenský fond spočívá $v$ majetku vyčleněném $z$ vlastnictví zakladatele, tento majetek je svěřen správci, jenž se zaváže jej držet a spravovat pro obmyšleného. Vznikem svěřenského fondu vzniká oddělené a nezávislé vlastnictví vyčleněného majetku a svěřenský správce je povinen ujmout se tohoto majetku a jeho správy. Vlastnická práva k majetku ve svěřenském fondu vykonává vlastním jménem na účet fondu svěřenský správce, přičemž majetek ve svěřenském fondu není ani vlastnictvím správce, ani vlastnictvím zakladatele, ani vlastnictvím osoby, které má být ze svěřenského fondu plněno. Zároveň se nejedná o majetek ničí, nebot' vlastnická práva k autonomnímu majetku vyčleněnému do fondu vykonává správce.

Z funkčního hlediska jej lze přirovnat k nadačnímu fondu, ovšem s tím základním rozdílem, že se nejedná o právnickou osobu - svěřenský fond nemá právní osobnost. ${ }^{46}$ Svěřenský fond má věcněprávně-obligační charakter, není natolik svázán statusovými otázkami jako právnické osoby, nabízí flexibilní řešení nejrůznějších životních situací od uchování celistvosti majetku, přes jeho ochranu, správu, až po nejrůznější zajišt'ovací instituty ${ }^{47}$. Jedním z vybízejících se příkladů možného využití je právě správa výživného určeného k tvorbě úspor dítěte.

\section{Konstrukce svěřenského fondu sloužícího ke správě úspor dítěte}

V předchozí kapitole jsme nastínili hlavní charakteristiky svěřenského fondu a jeho fungování. Tato kapitola má za cíl vysvětlit, z jakého důvodu se domníváme, že svěřenský fond má své využití při správě výživného určeného k tvorbě úspor, proč by mohl být řešením shora nastíněných problémů se správou prostředků dítěte tímto způsobem naspořených, a navrhneme také základní rysy vhodné právní úpravy, která by využití svěřenského fondu k tomuto účelu umožnila.

Hlavní výhodou svěřenského fondu je, že právní úprava nastavení vztahů mezi zakladatelem, svěřenským správcem a obmýšleným má dispozitivní povahu (limitují ji pouze obecné zásady jako zákaz zneužití práva, ochrana práv třetích osob apod.), proto je možné fungování svěřenského fondu nastavit tak, aby vyhovovalo zájmům a představám zúčastněných stran. Těmi na obecné rovině bude zakladatel, svěřenský správce a obmyšlený.

45 Viz důvodová zpráva k občanskému zákoníku.

46 Shodně též SPÁČIL, Jiří a kol. Občanský qákoník III. Věcná práva (』 976-1474). Komentár. 1. vyd., Praha: C. H. Beck, 2013, s. 1153 či RONOVSKÁ, Kateřina. Nadace (a trusty) v kontinentální Evropě: Pohled funkcionální. Obchodněprávní revue, Praha, C. H. Beck., vol. 4, no. 7-8/2012, s. 202-206.

47 Srov. VITOUL, Vlastimil. Svěřenský fond a jeho místo v českém právním prostředí. Masarykova univerzita. Dny práva - 2012 - Days of Law. Brno: Masarykova univerzita, 2013, s. 1246 a násl. 
Za současné právní úpravy je pro vznik svěřenského fondu nezbytná existence statutu svěřenského fondu, smluvní ujednání mezi zakladatelem a správcem o výkonu funkce správce faktické ujmutí se výkonu této funkce, tedy držby a správy vyčleněného majetku. Považujeme za nešt’astné, že český zákonodárce na rozdíl od quebeckého občanského zákoníku neumožnil vznik svěřenského fondu též ze zákona nebo na základě rozhodnutí soudu. Jediný případ možnosti vzniku trustu rozhodnutím soudu v Quebecu je totiž právě za účelem zajištění výživného příbuzného ${ }^{48}$. Pokud by české soudy mohly zřizovat svěřenský fond, jednalo by se o jeho efektivní využití pro řešení složitých životních situací, kdy smírné řešení není možné.

Takový rozsudek by měl obsahovat samotné vyslovení, že je trust založen, dále by musel určit jeho zakladatele a správce, povinnosti správce, osobu obmyšlenou, jaký způsobem budou do trustu vloženy (nebo vkládány) finanční prostředky, musel by také specifikovat dávky výživného, které mají být vypláceny obmyšlenému, a musel by dále určit, za jakých podmínek trust zaniká. ${ }^{49} \mathrm{Jde}$ tedy ve své podstatě o tytéž náležitosti, které dle současné české právní úpravy určuje statut svěřenského fondu, který mimo určení obmyšleného a určení majetku do svěřenského fondu vyčleněného a podmínek pro plnění ze svěřenského fondu obmýšlenému musí obsahovat též označení svěřenského fondu, vymezení účelu a údaj o době trvání fondu. V souladu se současnou českou právní úpravou však na obsahu statutu má formálně vliv pouze zakladatel, nebot' ten je osobou, jež statut formou veřejné listiny vydává. ${ }^{50}$ Soudní rozsudek vydaný podle quebecké právní úpravy může vedle prrímého zřízení trustu taktéž pouze stanovit povinnost, aby byl trust založen a určit částku, která do něj má být vložena. I v takovém případě však může být zřízení trustu následně homologováno soudem. ${ }^{51}$

Quebecký trust zřízený soudem za účelem zajištění plateb výživného může mít dvojí podobu - bud’to bude zř́izen primárně za účelem výplaty dávek výživného, kdy na počátku bude zakladatelem (povinným) vložena do trustu určitá částka, ze které následně budou vypláceny dávky výživného obmyšlenému (oprávněnému) nebo může být zrrízen primárně za zajištěním opakovaných plateb ze strany povinného. ${ }^{52} \mathrm{~V}$ českém právním prostředí považujeme za využitelné obě formy, nicméně pro účely správy výživného určeného k tvorbě úspor by posoužila druhá z uvedených forem, tedy ta, jejímž primárním cílem je zajištění hrazení pravidelných částek do trustu (svěřenského fondu). Bylo by za jistých okolností myslitelné i založení svěřenského fondu, do nějž by byla na počátku vložena

$48 \mathrm{~K}$ tomu více PIHERA, Vlastimil. Nejpodivnější zvíře v lese - poznámky ke svěřenskému fondu. Obchodnéprávni revue. 2012, č. 10 , s. 278.

49 Obdobně je tomu v Quebecu, viz CLAXTON, John B. Studies on the Quebec Law of Trust. Toronto: Thomson Carswell, 2005, s. 82.

50 Srov. ustanovení \ 1452 občanského zákoníku.

51 CLAXTON, John B. Studies on the Quebec Law of Trust. Toronto: Thomson Carswell, 2005, s. 83.

52 Tamtéž. 
určitá částka, a jehož primárním cílem by bylo vyplácení pravidelných dávek výživného. Nicméně současný stav, kdy je běžné výživné hrazeno k rukám rodiče, jemuž je dítě svěřeno do péče, považujeme za vyhovující a na rozdíl od správy výživného určeného k tvorbě úspor není současná praxe v zásadě problematická.

V současné chvíli česká právní úprava neumožňuje zř́izení svěřenského fondu soudním rozhodnutím. Domníváme se, že by však bylo možné, aby soud uložil povinnému rodiči povinnost svěřenský fond zř́idit, podobně jako je v současnosti ukládána povinnost založit účet, na nějž jsou částky vkládány. ${ }^{53}$ I takové řešení má však celou řadu úskalí. V první řadě za současné právní úpravy narážíme především na skutečnost, že zákon výslovně stanoví, že výživné přechází do vlastnictví dítěte. ${ }^{54} \mathrm{~V}$ př́padě svěřenského fondu prritom, jak bylo výše uvedeno, nejsou prostředky vložené do svěřenského fondu ve vlastnictví obmyšleného. Uložení povinnosti hradit výživné do svěřenského fondu by tak bylo v rozporu s předmětným ustanovením.

Nadto za současného stavu, kdy v České republice, na rozdíl od zemí, kde trusty a trust-like instituty mají svoji tradici, nemáme dosud žádnou evidenci osob, které by vykonávaly funkci svěřenského správce profesionálně. Právě svěřenský správce vykonává po vzniku svěřenského fondu plnou správu majetku ve svěřenském fondu ve smyslu ustanovení \1409 a násl. občanského zákoníku. Svěřenský správce tedy může s majetkem činit cokoliv, co je nutné a užitečné pro naplnění smyslu a účelu svěřenského fondu. Jakkoliv by v prrípadě svěřenského fondu zřízeného ke správě výživného určeného k tvorbě úspor byl svěřenský správce vázán imperativem nejlepšího zájmu dítěte, klade výkon této funkce na osobu ji vykonávající velmi vysoké nároky. Pokud by tedy soud pouze uložil povinnost povinnému rodiči svěřenský fond zrrídit, bylo by problematické vybrat vhodného svěřenského správce, který by finanční prostředky skutečně spravoval ve prospěch dítěte, a nikoliv ve prospěch jednoho z rodičů.

Jako mnohem prrípadnější se nám proto jeví takové řešení, kdy by zákonodárce provedl novelizaci současné právní úpravy svěřenských fondů a výslovně zakotvil možnost soudu zř́idit svým rozsudkem svěřenský fond, a to za účelem správy majetku dítěte představovaného částkami výživného, jež by byly do takto vytvořeného svěřenského fondu hrazeny, a to bud’ výhradně ke správě výživného určeného k tvorbě úspor, anebo ke správě výživného obecně. $\mathrm{V}$ takovém rozsudku by bylo specifikováno, kdo bude vykonávat funkci svěrenského správce (tuto osobu by soud zvolil s přihlédnutím k předpokladům spravovat majetek ve prospěch dítěte). Dále by soud do rozsudku vtělil statut svěřenského fondu, který by obsahoval pravidla pro správu majetku. Dle konkrétní situace konkrétního dítěte, by měl možnost více či méně přesně definovat, jaké platby a za jakých okolností budou dítěti či jeho zákonnému zástupci, který má dítě v péči, poskytovány.

53 Důvodová zpráva k zákonu č. 89/2012, občanskému zákoníku, k 『915 až 918. SVOBODA, Karel. K tvorbě úspor ve prospěch dítěte. Pránni roz̧bledy, 2014, č. 12, s. 437.

54 Srov. ustanovení \ 917 občanského zákoníku. 
Případně lze dále stanovit, že finanční prostředky mají být svěřenským správcem použity $\mathrm{k}$ předem stanovenému účelu, kdy by úhradu provedl prrímo svěřenský správce na účet svěrenského fondu.

Lze si tak představit, že soud určí, že ze svěřenského fondu budou hrazeny pravidelně určité částky ve prospěch dítěte, k jeho rukám nebo k rukám jeho zákonného zástupce, a to od konkrétního data v budoucnu či nastane-li v budoucnu určitá okolnost (např́klad $\mathrm{v}$ prrípadě smrti či ztráty př́jmu povinného). Naspořené prostředky lze taktéž účelově vázat. Svěřenský správce by tak mohl vydávat finance např́klad výhradně k úhradě školného nebo léčebných výloh dítěte. Lze uvažovat taktéž o méně konkrétním vymezení, kdy by prostředky nebyly vázány na žádný konkrétní účel, ani by nebylo jinak stanoveno, jakým konkrétním způsobem má svěřenský správce s majetkem dítěte nakládat. V takovém případě by byl vázán pouze imperativem nejlepšího zájmu dítěte. Správce by tedy $\mathrm{v}$ souladu s účelem výživného určeného $\mathrm{k}$ tvorbě úspor mohl nakládat s majetkem vyčleněným do svěřenského fondu tak, aby sloužil krytí potřeb dítěte $\mathrm{v}$ bezprostřední i vzdálené budoucnosti, a to ke krytí potřeb předem definovaných i neočekávaných a nepředvídaných.

Rozsudek by měl být v př́ipadě stanovení výživného určeného $\mathrm{k}$ tvorbě úspor vydáván s doložkou rebus sic stantibus, tedy s výhradou změny poměrů, tak jako je tomu i v př́ipadě soudního rozhodování o výživném obecně55, a mohl by tak být soudem v budoucnu změněn. Taková změna by mohla spočívat jak ve změně ustanovení správce, ve změně účelového určení finančních prostředků, tak i ve změně či ukončení uložené povinnosti hradit do svěřenského fondu určitou částku. Nové rozhodnutí by mohlo reagovat nejen na změnu poměrů na straně povinného nebo oprávněného, jako je tomu v rozhodování o výživném běžně ${ }^{6}$, ale taktéž např́lklad tehdy, ukáže-li se, že je třeba změnit dříve stanovený účel, k němuž mají být prostředky využity, nově jej stanovit pokud dosud stanoven nebyl nebo naopak ukáže-li se, že dosud stanovené účelové určení již není potřebné.

Navrhované řešení správy výživného určeného k tvorbě úspor tedy, jak vyplynulo ze shora uvedeného, předpokládá novelizaci současné právní úpravy. Za současného stavu však lze doporučit využití svěřenského fondu rodičům, kteří se rozhodnou otázku výživného pro dítě vyřešit smírnou cestou, nebot' zákon ukládá soudní úpravu vyživovací povinnosti pouze tehdy, pokud se rozvádí sezdaní rodiče dítěte ${ }^{57}$ nebo tehdy, nedohodnou-li se rodiče na hrazení výživného. Jak bylo výše uvedeno, vkládání prostředků do svěřenského fondu může účelně předcházet obávanému zneužívání prostředků ze strany povinného či oprávněného rodiče dítěte a může být efektivním prostředkem zajištění

\footnotetext{
55 ŠÍNOVÁ, Renata a kol. Aktuální problémy rodinněprávni regulace: rodicouství, výchova a výživa nezleteilébo. Praha: Leges, 2013, s. 194.

56 Tamtéž, s. 196-197.

57 K tomu blíže HRUŠÁKOVÁ, Milana, KRÁLÍČKOVÁ, Zdeňka, WESTPHALOVÁ, Lenka a kol. Občanský zákoník. II. Rodinné právo (\ 655 - 975). Praha: C. H. Beck, 2014, s. 452.
} 
správy majetku ve prospěch nezletilého dítěte. V případě dohody rodičů o vkládání výživného určeného $\mathrm{k}$ tvorbě úspor do svěřenského fondu může být volba osoby svěřenského správce taktéž výsledkem dohody rodičů, svěřenský fond tak může spravovat člověk, kterému oba rodiče důvěřují. Takové ujednání může přispět ke zvýšení ochoty povinného rodiče výživné hradit, nebot' se eliminuje riziko zneužití prostředků pečujícím rodičem, což je obvykle ta nejčastější z obav povinného rodiče.

\section{Závěr}

Lze tedy uzavřít, že současná právní úprava výživného určeného k tvorbě úspor je poněkud problematická. Mnohé nejasnosti panují ohledně toho, kdy vůbec tuto povinnost rodiči ukládat, za jakým účelem prostředky spořit, kdo má rozhodovat o tom, k čemu budou určeny a také kdy je lze využívat. Vůbec jako neproblematičtější se však jeví otázka správy výživného určeného k tvorbě úspor. Jak bylo výše uvedeno, tato úprava přinášî značné výkladové problémy a praxe ani doktrína nejsou jednotné v tom, jak by v současnosti měla podle zákona správa úspor probíhat. Nadto žádný z možných modelů správy, které v současnosti přicházejí v úvahu, nelze považovat za zcela vyhovující, nebot' ponechávají př́lišný prostor pro zneužití finančních prostředků pečujícím rodičem, nebo nejsou dostatečně flexibilní.

Cílem příspěvku bylo představit svěřenský fond jako flexibilní nástroj správy majetku obecně a poukázat na jeho možné užití právě pro účely správy výživného určeného k tvorbě úspor. Nespornou výhodou svěrenského fondu je jeho flexibilita - práva a povinnosti všech zúčastněných stran mohou být v rámci naplnění zásady dispozitivnosti nastaveny tak, aby byl respektován nejlepší zájem dítěte (obmyšleného), a zároveň poskytují dostatečnou jistotu obou rodičů, že prostředky dítěte nebudou zneužity.

Příspěvek přináší konkrétní návrh vhodné právní úpravy, která by umožnila soudu přímo zř́dit svěřenský fond a vtělit statut svěřenského fondu do výroku svého rozhodnutí. Správce takto zřízeného svěřenského fondu by byl povinen vykonávat správu s péči rádného hospodáře, tedy i s povinností nahradit na účet svěřenského fondu veškerou škodu, kterou by zpơsobil porušením svých povinností plynoucích z výkonu této funkce. Při výkonu své funkce by byl přitom vázán imperativem nejlepšího zájmu dítěte. Svěřenský fond lze pro hrazení výživného určeného k tvorbě úspor využít i za současné situace, avšak pouze za předpokladu, že je přítomna vưle zúčastněných stran se dohodnout. Autoři tedy uzavírají, že umožnění zřízení svěřenského fondu pro správu výživného určeného k tvorbě úspor rozhodnutím soudu by bylo vhodným řešením současné patové situace, kdy právní úprava nedostatečně chrání zájem dítěte na tom, aby jeho prostředky byly spravovány efektivně, a zároveň neposkytuje rodičům dítěte dostatečnou jistotu, že prostředky nebudou zneužity. 